Jurnal Keperawatan Silampari

Volume 2, Nomor 2, Juni 2019

e-ISSN: 2581-1975

p-ISSN: 2597-7482

DOI: https://doi.org/10.31539/jks.v2i2.529

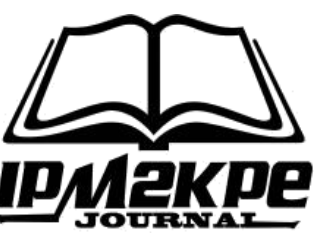

\title{
PENGARUH PIJAT OKSITOSIN OLEH SUAMI TERHADAP PENINGKATAN PRODUKSI ASI PADA IBU NIFAS
}

\author{
Tabita Mariana Doko ${ }^{1}$, Kun Aristiati ${ }^{2}$, Suhoryo Hadisaputro ${ }^{3}$ \\ Program Kebidanan Sains Terapan Pascasarjana, Poltekkes Kemenkes Semarang ${ }^{1,2,3}$ \\ marianadoko20@gmail.com ${ }^{1}$
}

\begin{abstract}
ABSTRAK
Tujuan dalam penelitian ini adalah membuktikan dan mengitifikasi pengaruh pijat oksitosin oleh suami terhadap peningkatan produksi ASI pada ibu nifas. Metode dalam penelitian ini menggunakan metode quasy eksperiment dengan pendekatan rancangan non equivalent control group design. Hasil penelitian, pemberian pijat oksitosin oleh suami berpengaruh terhadap peningkatan produksi Air Susu Ibu (ASI) dengan indikator berat badan bayi $(p<0.05)$, frekuensi menyusui $(p<0.05)$, lama tidur bayi $(p<0,05)$, frekuensi buang air besar bayi $(\mathrm{BAB})(\mathrm{p}<0,05)$, frekuensi buang air kecil bayi $(\mathrm{BAK})$ $(\mathrm{p}<0,05)$, dan istirahat tidur ibu $(\mathrm{p}<0,05)$. Simpulan, pemberian pijat oksitosin oleh suami dapat meningkatkan produksi Air Susu Ibu (ASI) pada ibu nifas yang dilihat dengan berat badan bayi hari, frekuensi menyusui, lama tidur bayi, frekuensi Buang Air Besar bayi (BAB), frekuensi Buang Air Kecil bayi (BAK), dan istirahat tidur ibu.
\end{abstract}

Kata Kunci: Ibu Nifas, Pijat Oksitosin oleh Suami, Produksi Air Susu Ibu (ASI)

\begin{abstract}
The purpose of this study was to prove and verify the effect of oxytocin massage by the husband on increasing milk production in postpartum mothers. The method in this study uses a quasy experimental method with a non equivalent control group design approach. The results of the study, the administration of oxytocin massage by the husband affected the increased production of breast milk (ASI) with indicators of infant weight ( $p<0.05)$, frequency of breastfeeding $(p<0.05)$, length of sleep of infants $(p$ $<0.05)$, frequency of discharges baby defecate $(B A B)(p<0.05)$, frequency of urination of infants $(B A K)(p<0.05)$, and resting mother's sleep $(p<0.05)$. Conclusion, giving oxytocin massage by the husband can increase the production of Breast Milk (ASI) in postpartum mothers seen by the weight of the baby today, frequency of breastfeeding, length of sleep of infants, frequency of defecation of infants (BAB), frequency of defecation of infants (BAK) ), and resting mother's sleep.
\end{abstract}

Keywords: Postpartum Mother, Oxytocin Massage by Husband, Breast Milk Production $(A S I)$ 


\section{PENDAHULUAN}

Peran ibu sangat penting dalam awal perkembangan anak ketika proses kehamilan hingga pasca kelahiran. Memberikan ASI eksklusif pada bayi baru lahir merupakan cara terbaik terbaik untuk pertumbuhan dan perkembangan (Aidam, 2005). ASI tidak hanya akan meningkatkan kekebalan tubuh secara alami, tetapi juga akan membentuk jalinan kasih sayang atau yang disebut dengan bounding antara bayi dan ibu. ASI merupakan zat gizi alamiah terbaik bagi bayi karena mengandung kebutuhan energi dan zat yang dibutuhkan selama enam bulan pertama kehidupan bayi. ASI merupakan susu segar dan steril yang diproduksi langsung oleh ibu dan dapat mengurangi gangguan pencernaan, dibandingkan dengan makanan lain jika ditelan oleh bayi (Ahn, 2011).

World Health Organization (WHO) mengeluarkan standar pertumbuhan anak yang kemudian diterapkan diseluruh belahan dunia. Isinya adalah menekankan pentingnya pemberian ASI saja kepada bayi sejak lahir sampai usia 6 bulan, ini berarti bahwa bayi hanya menerima ASI dari ibu, tanpa tambahan cairan atau makanan padat lain. Setelah bayi lahir, nutrisi memainkan peran terpenting bagi pertumbuhan dan perkembangan yang sehat bagi bayi. WHO menetapkan bahwa target ditahun 2025 sekurang-kurangnya 50\% dari jumlah bayi dibawah usia enam bulan diberikan ASI Eksklusif (WHO, 2013). Data UNICEF menjelaskan bahwa hanya 32,6\% dari mereka yang disusui secara eksklusif selama 6 bulan pertama. Di negara berkembang hanya 39\% ibu-ibu yang memberikan ASI Eksklusif (Siregars, 2006). Di Asia Tenggara capaian ASI eksklusif menunjukkan angka tidak banyak berbeda. Sebagai perbandingan, cakupan ASI eksklusif di India mencapai 46\%, di Philipina 34\%, di Vietnam 27\% dan Myanmar 24\%. Anak -anak yang mendapatkan ASI eksklusif empat belas kali lebih mungkin untuk bertahan hidup dalam enam bulan pertama kehidupan dibandingkan anak yang tidak disusui. Mulai menyusui pada hari pertama setelah lahir dapat menyurangi resiko kematian bayi baru lahir hingga 45\% (UNICEF, 2014).

Jumlah ibu menyusui $42 \%$ namun, hanya $44 \%$ yang berhasil menyusui pada 1 jam pertam setelah lahir dan hanya $62 \%$ dalam hari pertama setelah lahir serta 50,8\% dalam 1 bulan pertama. Laktasi dini atau pemberian ASI awal pada jam pertama setelah lahir akan merangsang terjadinya peningkatan prolaktin dalam darah dan mencapai puncak pada 45 menit pertama.

Ketua Sentra Laktasi Indonesia (SLI), Dr. Utami Roesli mengatakan bahwa kemungkinan meninggalnya bayi akibat terserang berbagai penyakit infeksi akan lebih mudah terjadi jika seorang ibu yang baru melahirkan tidak segera memberikan Air Susu Ibu (ASI) kepada bayinya. Salah satu kematian bayi dan balita tersebut adalah faktor gizi, dengan penyebab antara lain karena buruknya pemberian ASI eksklusif. (http://health.detik.com, 2011). Berdasarkan Riset Kesehatan Dasar (Riskesdas) (2013) angka cukupan ASI ini jelas dibawah target World Health Organisation (WHO) yang mengharuskan cakupan ASI minimal 50\% (WHO, 2013).

Menurut data profil kesehatan Indonesia 2016 tentang cakupan ASI eksklusif secara nasional pada bayi 0-5 bulan sebesar 54,0\%, dan bayi sampai usia enam bulan adalah sebesar 29,5\%. Sedangkan di Jawa Tengah Cakupan pemberian ASI Esksklusif pada bayi $0-5$ bulan sebesar $43,3 \%$, dan bayi usia enam bulan $25,4 \%$ sehingga perlu sosialisasi ASI pada ibu melahirkan untuk memberikan ASI secara Eksklusif sampai bayi umur 6 bulan tanpa makanan tambahan lain. Pada sidang Kesehatan Dunia ke-65, negara-negara anggota WHO menetapkan bahwa target di tahun 2025 sekurangkurangnya $50 \%$ dari jumlah bayi dibawah usia 6 bulan diberikan ASI eksklusif (Hubertin, 2004). 
Survei di Indonesia melaporkan bahwa 38\% ibu berhenti memberikan ASI karena kurangnya produksi ASI. Air susu ibu yang tidak lancar menjadikan ibu merasa cemas dan menghindar untuk menyusui dan berdampak pada kurangnya isapan bayi, hal tersebut mempengaruhi penurunan produksi dan kinerja hormon oksitosin dan prolaktin sehingga produksi ASI semakin menurun, bahkan menyebabkan pembendungan dan statis ASI, sehingga ibu mengambil langkah berhenti menyusui dan mengganti dengan susu formula. Menyusui dapat berperan dalam menurunkan angka kematian anak.Hal tersebut diperkuat oleh WHO yang menetapkan the international code of martketing of breastmilk substitutes mengenai larangan pemasaran susu formula kepala petuga kesehatan, karena pemasaran susu formula bayi 0-6 merupakan pelanggaran kode etik, dan bayi diharuskan mendapat ASI selama 6 bulan pertama dilanjutkan hingga umur 2 tahun serta didampingi oleh makanan pendamping ASI (MP-ASI) (Kim et al, 2018)

Menteri kesehatan telah memberikan atauran larangan untuk periklanan susu formula baik lewat media cetak, media elektronik, maupun media luar ruangan yang sudah diatur oleh UU Kesehatan no 36 tahun 2009 Pasal 128 yang menekankan hak bayi untuk mendapatkan ASI eksklusif kecuali atas indikasi medis (Jateng, 2013).

Peraturan Pemerintah Republik Indonesia Nomor 33 Tahun 2012 tentang pemberian ASI eksklusif pasal 6 berbunyi setiap ibu yang melahirkan harus memberikan ASI eksklusif kepada bayi yang dilahirkannya. UU Nomor 36/2009 pasal 128 ayat 2 dan 3 disebutkan bahwa selama pemberian ASI, pihak keluarga, pemerintah daerah dan masyarakat harus mendukung ibu secara penuh. Oleh karena itu, ibu membutuhkan dukungan keluarga dalam pelaksanaan pijat oksitosin khususnya keluarga yang paling dekat dengan ibu yaitu suami. Kurangnya dukungan yang diberikan pada ibu dan kesulitan untuk menyusui dini dapat menyebabkan produksi ASI terhambat dan jumlah ASI yang keluar tidak cukup (Jateng, 2013). Hal ini menunjukkan bahwa keputusan seorang ibu untuk menyusui membutuhkan dukungan dari suami dan keluarga yang berguna bagi tumbuh kembang yang optimal baik fisik maupun mental dan kecerdasannya. Dukungan yang diberikan oleh keluarga kepada ibu nifas dapat membuat ibu memiliki keyakinan dan rasa percaya diri bahwa dia mampu untuk memproduksi ASI yang cukup untuk bayinya sehingga produksi ASI menjadi lancar. Jadi, dukungan keluarga sangat berperan penting dalam keberhasilan pemberian ASI eksklusif (Dewi, Santika, 2017).

Dukungan orang terdekat khususnya suami sangat dibutuhkan dalam mendukung ibu selama memberikan ASI-nya sehingga memunculkan istilah breast feeding father atau ayah menyusui. Jika ibu merasa didukung, dicintai, dan diperhatikan maka akan muncul emosi positif yang akan meningkatkan produksi hormon oksitosin sehingga produksi ASI pun lancar. Dukungan keluarga, teman, dan petugas kesehatan juga mempengaruhi keberhasilan menyusui. Bila suami atau keluarga dapat mengambil alih sebagian tugas ibu di rumah, ibu tentu tidak akan kelelahan. Persiapan ibu secara psikologis sebelum menyusui merupakan faktor penting yang mempengaruhi keberhasilan menyusui. Dengan adanya keluarga dan lingkungan yang mendukung dalam pemberian ASI dapat mengurangi kecemasan dan stres ibu (Hani, 2014). Dukungan suami maupun keluarga lain dalam rumah akan sangat membantu berhasilnya seorang ibu untuk menyusui. Perasan ibu yang bahagia, senang, perasan menyayangi bayi, memeluk, mencium, dan mendengar bayinya menangis akan meningkatkan pengeluaran ASI. Jadi, dukungan suami maupun keluarga lain dalam rumah akan sangat membantu berhasilnya seorang ibu untuk menyusui (Rempe, 2017) 
Oleh karena itu, upaya yang dilakukan oleh Dinas Kesehatan Semarang untuk meningkatkan cakupan ASI Esklusif dengan melakukan Inisiasi Menyusui Dini (IMD) pada asuhan persalinan normal (APN), promosi dan konseling laktasi, kelompok pendudung ASI, namun cakupan ASI eksklusif belum maksimal sehingga dilakukan upaya alternatif untuk meningkatkan produksi ASI salah satunya dengan pemberian pendidikan dan konseling perawatan payudara, penyuluhan gizi ibu nifas, teknik menyusui yang baik dan benar, pemberian support mental ibu nifas, tetapi beberapa upaya diatas belum dapat meningkatkan produksi ASI secara optimal. Produksi ASI sangat di pengaruhi oleh kejiwaan, ibu yang selalu dalam keadaan tertekan, sedih kurang percaya diri dan berbagai bentuk ketegangan emosional akan menurunkan volume ASI bahkan produksi ASI berhenti sama sekali. Penurunan produksi dan pengeluaran ASI dan pengeluaran ASI pada hari-hari pertama setelah melahirkan dapat disebabkan oleh kurangnya rangsangan hormon prolaktin dan oksitosin yang sangat berperan dalam kelancaran produksi dan pengeluaran ASI (Semarang, 2015).

Produksi dan pengeluaran ASI dipengaruhi oleh hormon prolaktin dan oksitosin dan reflek prolaktin dan let-down reflex. Hormon prolaktin dikeluarkan saat ada stimulasi pada saat bayi mengisap puting susu ibu, gerakan isapan bayi merangsang serat saraf dalam puting susu ibu. Serat saraf ini membawa permintaan agar air susu melewati kolumna spinalis ke kelenjar hipofisis dalam otak. Kelenjar hipofisis merespon pesan ini dengan melepas hormon prolaktin dan oksitosin. Hormon Prolaktin merangsang payudara untuk menghasilkan lebih banyak air susu. Oksitosin merangsang kontraksi otot-otot yang sangat kecil yang melindungi duktus dalam payudara. Kontraksi ini menekan duktus dan mengeluarkan air susu dalam tempat penampungan dibawah areola dan masuk ke sistem duktulus untuk selanjutnya mengalir masuk ke dalam dalam mulut bayi. Berdasarkan teori, hypogactia terjadi karena adanya hambatan dalam produksi hormon prolaktin pada tahapan laktogenesis yang disebabkan adanya congenital dysplasia, masalah diet (Morhenn, 2012).

Teknik untuk memperbanyak produksi ASI antara lain perawatan payudara atau breast care, senam payudara, pemijatan payudara dan pijat oksitosin. Sebagai alternatif, dilakukan berbagai penelitian untuk menemukan terapi pengganti yang lebih aman sehingga dapat meningkatkan produksi ASI seperti terapi non farmakologis seperti terapi herbal, pijat oksitosin, pijat marmet, pijat endorpin, kompres hangat, breast care dan aroma terapi. Tetapi karena keterbatasan informasi di layanan kesehatan tentang prosedur pelaksanaan maka metode-metode ini jarang diberikan oleh tenaga kesehatan sebagai care giver kepada pasien (Latifah, 2015).

Pijat oksitosin merupakan salah satu solusi untuk mengatasi ketidak lancaran produksi ASI. Pemijatan oksitosin adalah pemijatan pada sepanjang sisi tulang belakang sampai tulang costae kelima-keenam dan merupakan usaha untuk merangsang hormon prolaktin dan okstosin setelah melahirkan. Pijat oksitosin tidak dapat dilakukan oleh ibu karena pijat oksitosin ini dilakukan disepanjang tulang belakang ibu (Khairani, 2012). Oleh karena itu, ibu membutuhkan dukungan keluarga dalam pelaksanaan pijat oksitosin khususnya keluarga paling terdekat dengan ibu yaitu suami. Manfaat dari penerapan pijat oksitosin berfungsi untuk meningkatkan hormon oksitosin yang dapat menyenangkan ibu, sehingga ASI pun otomatis keluar. Efek pijat oksitosin adalah sel kelenjar payudara mensekresi ASI sehingga bayi mendapatkan ASI sesuai dengan kebutuhan dan berat badan bayi bertambah (Eko, 2011)

Sebagaimana dalam European Journal of Neuroscience, bahwa perawatan pemijatan berulang bisa meningkatkan produksi hormon oksitosin. Efek dari pijat 
oksitosin itu sendiri bisa dilihat reaksinya setelah 6-12 jam pemijatan. Hal ini juga di bahas dalam penelitian di California tentang pengaruh pemijatan hipotamus-hipofisisadrenal dan fungsi imun dalam kesehatan, dengan hasil penelitian mengatakan adanya peningkatan hormon oksitosin dan menekan argainine-vasopressin (AVP) serta menekan hormon cortisol setelah dilakukan pemijatan (Sintesis, 2010).

Perawatan payudara atau breast care adalah pemeliharaan payudara yang dilakukan untuk memperlancar ASI dan menghindari kesulitan pada saat menyusui dengan melakukan pemijatan. Perawatan payudara sangat penting dilakukan selama hasil sampai menyusui. Hal ini karena payudara karena payudara merupakan satusatunya penghasil ASI yang merupakan makanan pokok bayi baru lahir sehingga harus dilakukan karena bertujuan memperlancar sirkulasi darah dan mencegah tersumbatnya saluran air susu sehingga memperlancar pengeluaran ASI dengan menjaga agar payudara senantiasa bersih dan terawat, karena saat menyusui payudara ibu akan kontak langsung dengan mulut bayi dan menghindari puting susu yang sakit dan infeksi payudara, serta menjaga keindahan bentuk payudara selain itu perawatan payudara juga bertujuan untuk meningkatkan produksi ASI dengan merangsang kelenjar air susu melalui pemijatan, mencegah bendungan ASI atau pembengkakan payudara, melenturkan puting, mengetahui secara dini kelainan puting susu dan melakukan usaha untuk mengatasinya. Breast care atau perawatan payudara merangsang reseptor di sistem duktus, menyebabkan duktus menjadi lebar dan lunak, sehingga secara reflekstoris dikeluarkannya oksitosin dari kelenjar hipofisis posterior (Latifah, 2015).

Breast care post partum adalah perawatan payudara pada ibu setelah melahirkan sedini mungkin. Perawatan payudara adalah suatu kegiatan yang dilakukan secara sadar dan teratur untuk memelihara kesehatan payudara dengan tujuan untuk mempersiapkan laktasi pada waktu post partum. Adapun pelaksanaan breast care post partum ini dilakukan pada hari ke 1 - 2 setelah melahirkan minimal 2 kali dalam sehari (J, 2005).

Studi pendahuluan dilakukan di wilayah kerja Puskesmas Pudakpayung kecamatan Banyumanik bulan Februari-Maret 2018 didapatkan data ibu nifas 160 orang. Berdasarkan hasil wawancara dengan bidan desa, didapatkan bahwa ibu yang menyusui masih banyak yang mengalami masalah pengeluaran ASI kurang lancar dikarenakan faktor frekuensi menyusi, paritas, stress, penyakit ataupun kesehatan ibu, konsumsi alkohol/rokok, pil kontrasepsi, asupan nutrisi dan belum mengetahui cara pijat untuk memperlancar ASI. Penyuluhan tentang pijat oksitosin belum pernah diberikan oleh bidan desa maupun petugas kesehatan dari puskesmas, tetapi materi lain seperti penyuluhan tentang perawatan payudara/breast care dan nutrisi/ gizi untuk memperlancar ASI sudah pernah diberikan.

Untuk meningkatkan produksi ASI diharapkan dapat dilakukan penerapan pijat oksitosin ini, memaksimalkan produksi dan keberlangsungan proses ASI. Menurut Widayanti (2014) Sehingga hasil pijat oksitosin tersebut dapat dijadikan sebagai solusi alternatif terhadap permasalahan yang dialami oleh ibu menyususi dalam proses pemberian ASI secara berkelanjutan.

\section{METODE PENELITIAN Desain Penelitian}

Penelitian ini menggunakan metode rancangan quasy eksperiment dengan rancangan non equivalent control group design yaitu salah satu eksperimen paling luas. Dan penelitian sebelumnya menggunakan eksperiment non randomized controlled trial desain pretest posttes control group. Desain kelompok perlakuan disebut kelompok 
intervensi diberi pijat oksitosin oleh suami dan breast care. Kelompok kontrol diberikan breast care kemudian diukur produksi ASI pada variabel dependent.

\section{Tempat Penelitian}

Penelitian ini dilakukan di wilayah Puskesmas Pudakpayung Kota Semarang, pada bulan April sampai Juni 2018.

\section{Populasi dan Sampel}

Populasi target 126 responden yang dipilih berdasarkan kriteria inklusi yaitu : Ibu tidak menggunakan kontrasepsi hormonal, umur 15 - 35 tahun, usia kehamilan aterm (37-42 minggu), berat badan lahir $\geq 2500$ gram dengan lahir cukup bulan. Perhitungan tersebut, total seluruh sampel berjumlah 40 orang. Berdasarkan estimasi jumlah minimal sampel diatas, maka pada penelitian ini menggunakan 40 sampel yang akan dibagi menjadi dua kelompok, yaitu kelompok intervensi dan kelompok kontrol.

\section{Instrument}

Instrumen penelitian yang digunakan pada penelitian ini meliputi lembar observasi pijat oksitosin, lembar observasi breast care dan lembar observasi bayi dengan melakukan pengamatan atau observasi langsung terhadap subjek penelitian yaitu penimbangan berat badan bayi (BB bayi), frekuensi menyusui, lama tidur bayi, frekuensi buang air besar (BAK), frekuensi buang air kecil (BAK), dan istirahat tidur ibu.

\section{Intervensi}

Pada kelompok intervensi diberikan pijat oksitosin oleh suami 2x sehari pagi dan sore selama 15 menit sampai hari ke 14. Pemijatan sepanjang kedua sisi tulang belakang ibu dengan menggunakan dua telapak tangan, dengan ibu jari menunjuk ke depan. Area tulang belakang leher. Cari daerah dengan tulang yang paling menonjol,namanya prosessus spinosus/cervical vertebrae 7 . Tindakan terapi pijat oksitosin oleh suami ini diajarkan pada suami oleh peneliti/enumerator sesuai dengan Standard Operating Procedure (SOP)yang telah dibuat sebelumnya serta responden diberikan evaluasi ulang setelah diajarkan pijat oksitosin oleh peneliti. Sedangkan pada kelompok kontrol diberikan breast careyang dilakukan oleh responden sendiri dan dipantau oleh peneliti/enumerator,breast care dilakukan $2 \mathrm{x}$ sehari pagi dan sore selama 15 menit sampai hari ke 14 sesuai dengan Standard Operating Procedure (SOP) yang telah dibuat sebelumnya serta responden diberikan evaluasi ulang setelah diajarkan breast careoleh peneliti/enumerator.

\section{Data Analisis}

Data hasil penelitian ini diuji menggunakan anilisis univariat, bivariate, dan multivariat. Kelompok pijat oksitosin oleh suami dan breast care. Kelompok Kontrol diuji menggunakan uji man whitneyuntuk mengetahui signifikansi dan perbedaan sebelum dan sesudah, kemudian dilakukan uji wilcoxon serta uji anova repeated measured untuk mengetahui signifikansi antar kedua kelompok. 


\section{Etika Penelitian}

Kelayakan etika penelitian ini diperoleh dari komite etika penelitian kesehatan (K.E.P.K) Politeknik Kesehatan Kemenkes Semarangdengan No: 274/KEPK/Poltekkessmg/EC/2018. Responden yang terlibat dalam penelitian ini memperoleh inform consent yang tepat.

\section{HASIL PENELITIAN}

\section{Karakteristik Partisipan (Variabel Counfounding)}

Distribusi Karakteristik partisipan dalam penelitian ini meliputi: umur ibu, umur suami, pendidikan ibu, pendidikan suami, pekerjaan suami, dan paritas. Karakteristik respon den dapat dilihat pada tabel berikut :

Tabel. 1

Karakteristik Partisipan menurut Kelompok Kontrol dan Kelompok Intervensi berdasarkan Umur Ibu, Umur Suami, Tingkat Pendidikan, Pekerjaan, Paritas

\begin{tabular}{|c|c|c|c|c|c|}
\hline \multirow{2}{*}{ Variabel } & & \multicolumn{2}{|c|}{ Intervensi $(n=20)$} & \multicolumn{2}{|c|}{ Kontrol $(\mathrm{n}=20)$} \\
\hline & & \multicolumn{2}{|c|}{ Mean \pm SD } & \multicolumn{2}{|c|}{$\operatorname{Min} \pm S D$} \\
\hline Umur Ibu (tahun) & & \multicolumn{2}{|c|}{$25,8 \pm 1,936$} & \multicolumn{2}{|c|}{$26,2 \pm 2,167$} \\
\hline Umur Suami (Tahun) & & \multicolumn{2}{|c|}{$29,5 \pm 1,504$} & \multicolumn{2}{|c|}{$29,4 \pm 1,847$} \\
\hline Pendidikan Ibu & & $\mathrm{N}$ & $\%$ & $\mathrm{~N}$ & $\%$ \\
\hline SMP & & 4 & 20 & 4 & 20 \\
\hline SMA & & 15 & 75 & 14 & 70 \\
\hline PT & & 1 & 5 & 2 & 10 \\
\hline Pendidikan Suami & N\% & & & $\mathrm{N}$ & \\
\hline SMP & & 1 & 5 & 1 & 5 \\
\hline SMA & & 16 & 80 & 17 & 85 \\
\hline PT & & 3 & 15 & 2 & 10 \\
\hline Pekerjaan Suami & & $\mathrm{N}$ & $\%$ & $\mathrm{~N}$ & $\%$ \\
\hline Swasta & & 8 & 40 & 9 & 45 \\
\hline Wiraswasta & & 8 & 40 & 6 & 30 \\
\hline PNS & & 2 & 10 & 1 & 5 \\
\hline Pabrik & & 2 & 10 & 4 & 20 \\
\hline Paritas & & $\mathrm{N}$ & $\%$ & $\mathrm{~N}$ & $\%$ \\
\hline Multipara & & 7 & 35 & 7 & 35 \\
\hline Primipara & & 13 & 65 & 13 & 65 \\
\hline
\end{tabular}

Mann-Whitney Test

Tabel 1 Hasil menunjukkan pada variabel umur ibu/partisipan kelompok intervensi didapatkan umur 25,8 tahun, umur temuda 24 tahun dan tertua 30 tahun. Sementara pada kelompok kontrol umur partisipan didapatkan mean 26,2 tahun dengan umur termudah 24 tahun dan umur tertua adalah 31 tahun. Umur pada kedua kelompok berbeda tetapi tidak bermakna $(\mathrm{p}=0.484)$, artinya karakteristik umur ibu/ responden pada kedua kelomok sama.

Variabel pada umur suami/responden kelompok intervensi didapatkan umur 29,5 tahun, dengan umur temuda 27 tahun dan tertua 32 tahun. Sementara pada kelompok kontrol umur ibu/responden didapatkan mean 29,4 tahun, dengan umur termudah 27 tahun dan umur tertua adalah 33 tahun. Umur pada kedua kelompok berbeda tetapi tidak 
bermakna ( $\mathrm{p}=0.183)$, artinya karakteristik umur suami/ responden kedua kedua kelomok sama. Pendidikan ibu/responden pada kelompok kontrol Sekolah Menengah Pertama 20\%, Sekolah Menegah Atas 70\%, dan Perguruan Tinggi 10\%. Sedangkan pendidikan ibu/responden pada kelompok intervensi Sekolah Menengah Pertama 20\%, Sekolah Menengah Atas 75\%, dan Perguruan Tinggi 5\%. Analisis kedua kelompok menggunakan uji homogenitas. Pendidikan pada kedua kelompok berbeda tapi tidak bermakna (pvalue>0,05), karakteristik pendidikan kedua kelompok sama.

Pendidikan suami/responden pada kelompok kontrol Sekolah Menengah Pertama 5\%, Sekolah Menegah Atas 85\%, dan Perguruan Tinggi 10\%. Sedangkan pendidikan suami/responden pada kelompok intervensi Sekolah Menengah Pertama 5\%, Sekolah Menengah Atas 80\%, dan Perguruan Tinggi 15\%. Analisis kedua kelompok menggunakan uji Mann-Whitney Pendidikan pada kedua kelompok berbeda tapi tidak bermakna $(\mathrm{p}=0,470)$, karakteristik pendidikan kedua kelompok sama.

Pekerjaan responden pada kelompk kontrol swasta 45\%, wiraswasta 30\%, PNS $5 \%$, dan buruh pabrik 20\% sedangkan pada kelompok intervensi swasta $40 \%$, wiraswasta $40 \%$, PNS $10 \%$ dan buruh pabrik 10\%. Analisis menggunakan uji mannwhitney kedua kedua kelompok berbeda tetapi tidak bermankna $(\mathrm{p}=0,704)$. Karakteristik kedua kelompok sama.

Paritas pada kelompok kontrol multipara 35\% dan primipara 65\%, pada kelompok intervensi multipara 35\% dan primipara 65\%. Analisis kedua kelompok menggunakan uji mann-whitney, paritas kedua kelompok berbeda tetapi tidak bermakna $(\mathrm{p}=1.00)$, karakteristik paritas kedua kelompok sama.

Dari hasil perhitungan diatas dapat disimpulkan bahwa karakteristik partisipan meliputi usia, pendidikan, dan paritas pada kelompok perlakuan dan kelompok kontrol adalah sama tidak mempengaruhi produksi ASI.

\section{Analisa Data Bivariat \\ Produksi Air Susu Ibu (ASI)}

Distribusi Karakteristik responden dalam penelitian ini meliputi : Istirahat tidur, frekuensi menyusui, berat badan bayi, frekluensi menyusui, lama tidur bayi, frekuensi $\mathrm{BAB}$, frekuensi $\mathrm{BAK}$, dan istirahat tidur. Karakteristik responden dapat dilihat pada tabel berikut :

Tabel. 2

Distribusi variabel dengan (produksi ASI) Menurut Kelompok Intervensi dan kelompok Kontrol (N=40). Berat Badan Bayi, Frekuensi Menyusui, Lama Tidur Bayi, Frekuensi BAB,

Frekuensi BAK, dan Istirahat tidur

\begin{tabular}{lccccc}
\hline & Mean \pm SD & Mean \pm SD & \multicolumn{2}{c}{ Median } & pvalue* \\
\cline { 2 - 4 } $\begin{array}{l}\text { Variabel } \\
\text { Berat Badan Bayi } \\
\text { (gram) }\end{array}$ & Perlakuan & Kontrol & Perlakuan & Kontrol & \\
$\quad$ Sebelum & $2696,5 \pm 201,8$ & $2678,25 \pm 217,19$ & 2570 & 2570 & 0,799 \\
$\quad$ Setelah & $3048,2 \pm 205,7$ & $2910,50 \pm 218,33$ & 7,50 & 6,00 & 0,003 \\
& & & & & \\
Frekuensi & & & & & \\
Menyusui(x/hari) & $7,25 \pm 0,444$ & $7,50 \pm 0,605$ & 7,00 & 7,50 & 0,157 \\
$\quad$ Sebelum & $11,45 \pm 0,604$ & $10,50 \pm 0,513$ & 11,50 & 10,50 & 0,000 \\
$\quad$ Setelah & & & & & \\
$\begin{array}{l}\text { Lama Tidur bayi } \\
\text { (jam/hari) }\end{array}$ & & & & & \\
\hline
\end{tabular}




\begin{tabular}{|c|c|c|c|c|c|}
\hline Sebelum & $10,15 \pm 0,356$ & $10,35 \pm 0,489$ & 10,0 & 10 & 0,289 \\
\hline Setelah & $11,70 \pm 0,470$ & $10,95 \pm 0,394$ & 12,0 & 11 & 0,000 \\
\hline \multicolumn{6}{|c|}{$\mathrm{BAB}(\mathrm{x} /$ hari $)$} \\
\hline Sebelum & $1,35 \pm 0,489$ & $1,45 \pm 0,510$ & 1,00 & 1,00 & 0,602 \\
\hline Setelah & $3,35 \pm 0,745$ & $2,40 \pm 0,503$ & 3,50 & 2,00 & 0,000 \\
\hline \multicolumn{6}{|c|}{ BAK(x/hari) } \\
\hline Sebelum & $5,25 \pm 0,444$ & $5,40 \pm 0,875$ & 5,00 & 5,00 & 0,429 \\
\hline Setelah & $9,55 \pm 0,605$ & $8,65 \pm 0,503$ & 10,0 & 9,00 & 0,000 \\
\hline \multicolumn{6}{|c|}{ Istirahat } \\
\hline \multicolumn{6}{|c|}{ Tidur(jam/hari) } \\
\hline Sebelum & $5,35 \pm 0,489$ & $5,45 \pm 0,503$ & 5,00 & 5,00 & 0,602 \\
\hline Setelah & $7,35 \pm 0,745$ & $6,40 \pm 0,503$ & 7,50 & 6,00 & 0,000 \\
\hline
\end{tabular}

\section{Rerata Berat Badan Bayi}

Berdasarkan tabel 2 menunjukkan rerata berat badan bayi sebelum diberikan perlakuan pada kelompok intevensi adalah 2696,5gram. Sedangkan rereta kelompok kontrol adalah 2678,25 gram. Hasil analisis lebih lanjut dengan uji wilcoxon didapatkan tidak ada perbedaan yang bermakna rerata berat badan bayi sebelum diberikan perlakuan antara kelompok intervensi dan kelompok kontrol $(\mathrm{p}=0.799)$.

Rerata berat badan bayi setelah diberikan perlakuan pada kelompok intervensi adalah 3048,2 gram. Sedangkan rerata pada kelompok kontrol adalah 2910,50 gram. Hasil analisis lebih lanjut dengan uji wilcoxon didapatkan ada perbedaan yang bermakna rerata berat badan bayi setelah diberikan perlakuan antara kelompok intervensi dan kelompok kontrol $(\mathrm{p}=0.003)$. Adapun pengaruh pemberian pijat oksitosin oleh suami dan breast care pada kelompok intevensi terlihat ada kenaikan rerata berat badan bayi yang lebih besar dibandingkan dengan kelompok kontrol.

Rerata selisih berat badan bayi pada kelompok intervensi adalah 351,75 gram. Sedangkan rerata selisih pada kelompok kontrol adalah 232,25 gram. Hasil uji analisis lebih lanjut dengan uji wilcoxon dapat disimpulkan ada perbedaan yang bermakna rerata selisih kenaikan berat badan bayi antara kelompok intervensi dengan kelompok kontrol $(\mathrm{p}=0.000)$.

Adapun pengaruh pemberian pijat oksitosin oleh suami dan breast care pada kelompokintervensi terlihat ada kenaikan rerata berat badan bayi yang lebih besar dibandingkan dengan kelompok kontrol.

\section{Rerata Frekuensi Menyusui Bayi}

Berdasarkan tabel 2 menunjukkan rerata frekuensi menyusui sebelum diberikan perlakuan pada kelompok intervensi adalah 7,25 x/hari. Sedangkan rereta kelompok kontrol adalah 7,50 x/hari. Hasil analisis lebih lanjut dengan uji wilcoxon didapatkan tidak ada perbedaan yang bermakna rerata frekuensi menyusui sebelum diberikan perlakuan antara kelompok intervensi dan kelompok kontrol $(\mathrm{p}=0.157)$.

Rerata frekuensi menyusui setelah diberikan intervensi pada kelompok intervensi adalah 11,45 x/hari. Sedangkan rerata pada kelompok kontrol adalah 10,50 x/hari. Hasil analisis lebih lanjut didapatkan ada perbedaan yang bermakna rerata frekuensi menyusui setelah diberikan intervensi antara kelompok intervensi dan kelompok kontrol $(\mathrm{p}=0.000)$. Adapun pengaruh pemberian pijat oksitosin oleh suami dan breast care pada kelompok intervensi terlihat ada kenaikan rerata frekuensi menyusui yang lebih besar dibandingkan dengan kelompok kontrol. 
Rerata selisih frekuensi menyusui pada kelompok intervensi adalah 4,20 x/hari. Sedangkan rerata selisih pada kelompok kontrol adalah $0,95 \mathrm{x} /$ hari. Hasil uji analisis lebih lanjut dengan uji wilcoxon dapat disimpulkan ada perbedaan yang bermakna rerata selisih kenaikan frekuensi menyusui antara kelompok intervensi dengan kelompok kontrol $(\mathrm{p}=0.000)$. Adapun pengaruh pemberian pijat oksitosin oleh suami pada kelompok intervensi terlihat ada kenaikan rerata frekuensi menyusui bayi yang lebih besar dibandingkan dengan kelompok kontrol.

\section{Rerata Lama Tidur Bayi}

Berdasarkan tabel 2 menunjukkan rerata lama tidur bayi sebelum diberikan perlakuan pada kelompok intervensi adalah 10,15 jam/hari. Sedangkan rereta kelompok kontrol adalah 10,35 jam. Hasil analisis lebih lanjutdengan uji wilcoxon didapatkan tidak ada perbedaan yang bermakna rerata lama tidur bayi sebelum diberikan perlakuan antara kelompok intervensi dan kelompok kontrol $(\mathrm{p}=0.285)$.

Rerata lama tidur bayi sesudah diberikan perlakuan pada kelompok intervensi adalah 11,70 jam/hari. Sedangkan rerata pada kelompok kontrol adalah 10,95 jam/hari. Hasil analisis lebih lanjut dengan uji wilcoxon didapatkan tidak ada perbedaan yang bermakna rerata berat badan bayi setelah diberikan perlakuan antara kelompok internsi dan kelompok kontrol $(\mathrm{p}=0,000)$. Adapun pengaruh pemberian pijat oksitosin oleh suami pada kelompok intervensi terlihat ada kenaikan rerata lama tidur bayi yang lebih besar dibandingkan dengan kelompok kontrol.

Rerata selisih lama tidur bayi pada kelompok intervensi adalah 1,55 jam/hari. Sedangkan rerata selisih pada kelompok kontrol adalah 0,60 jam. Hasil uji analisis lebih lanjut dengan uji wilcoxon dapat disimpulkan ada perbedaan yang bermakna rerata selisih kenaikan lama tidur bayi antara kelompok perlakuan dengan kelompok kontrol $(\mathrm{p}=0.000)$. Adapun pengaruh pemberianpijat oksitosin oleh suami dan breast care pada kelompok perlakuan terlihat ada kenaikan rerata lama tidur bayi yang lebih besar dibandingkan dengan kelompok kontrol.

\section{Rerata Buang Air Besar Bayi (BAB)}

Tabel 2 menunjukkan rerata buang air besar bayi (BAB) sebelum diberikan perlakuan pada kelompok intervensi adalah 1,35 x/hari. Sedangkan rereta kelompok kontrol adalah 1,45 $\mathrm{x} /$ hari. Hasil analisis lebih lanjut didapatkan tidak ada perbedaan yang bermakna rerata buang air besar bayi (BAB) sebelum diberikan perlakuan antara kelompok intervensi dan kelompok kontrol $(\mathrm{p}=0.602)$.

Rerata frekuensi buang air besar bayi (BAB) sesudah diberikan perlakuan pada kelompok intervensi adalah 3,35 x/hari. Sedangkan rerata pada kelompok kontrol adalah 2,40 x/hari. Hasil analisis lebih lanjut dengan uji wilcoxon didapatkan ada perbedaan yang bermakna rerata $\mathrm{BAB}$ bayi setelah diberikan perlakuan antara kelompok intervensi dan kelompok kontrol $(\mathrm{p}=0.000)$. Adapun pengaruh pemberian pijat oksitosin oleh suami dan breast care pada kelompok intervensi terlihat ada kenaikan rerata frekuensi buang air besar bayi (BAB) yang lebih besar dibandingkan dengan kelompok kontrol.

Rerata selisih BAB bayi pada kelompok intervensi adalah 2,00 x/hari. Sedangkan rerata selisih pada kelompok kontrol adalah $1,15 \mathrm{x} /$ hari. Hasil uji analisis mannwhitnney dapat disimpulkan tidak ada perbedaan yang bermakna rerata selisih kenaikan frekuensi buang air besar bayi (BAB) antara kelompok intervensi dengan kelompok kontrol $(\mathrm{p}=0.007)$. Adapun pengaruh pemberian pijat oksitosin oleh suami dan breast 
care pada kelompok intervensi terlihat ada kenaikan rerata frekuensi buang air besar bayi (BAB) yang lebih besar dibandingkan dengan kelompok kontrol.

\section{Rerata Buang Air Kecil Bayi (BAK)}

Berdasarkan tabel 2 menunjukkan frekuensi buang air besar bayi(BAK) sebelum diberikan perlakuan pada kelompok intervensi adalah 5,25 x/hari. Sedangkan rereta kelompok kontrol adalah 5,40 x/hari. Hasil uji analisis mann-whitnney didapatkan tidak ada perbedaan yang bermakna rerata frekuensi buang air kecil bayi (BAK) sebelum diberikan perlakuan antara kelompok intervensi dan kelompok kontrol $(\mathrm{p}=0.429)$.

Rerata frekuensi buang air kecil bayi (BAK) sesudah diberikan perlakuan pada kelompok intervensi adalah 9,55 x/hari. Sedangkan rerata pada kelompok kontrol adalah $8,65 \mathrm{x} /$ hari. Hasil analisis lebih lanjut dengan uji wilcoxon didapatkan tidak ada perbedaan yang bermakna rerata frekuensi buang air kecil bayi (BAK)setelah diberikan perlakuan antara kelompok intervensi dan kelompok kontrol $(\mathrm{p}=0,000)$. Adapun pengaruh pemberian pijat oksitosin oleh suami dan breast care pada kelompok intervensi terlihat ada kenaikan rerata frekuensi buang air kecil bayi (BAK) yang lebih besar dibandingkan dengan kelompok kontrol.

Rerata selisih frekuensi buang air kecil bayi (BAK) pada kelompok intervensi adalah 3,30 x/hari. Sedangkan rerata selisih frekuensi buang air kecil bayi (BAK) pada kelompok kontrol adalah 2,25x/hari. Hasil uji analisis lebih lanjut dengan uji wilcoxon dapat disimpulkan tidak ada perbedaan yang bermakna rerata selisih kenaikan frekuensi BAK bayi antara kelompok intervensi dengan kelompok kontrol $(\mathrm{p}=0.001)$.

Adapun pengaruh pemberian pijat oksitosin oleh suami pada kelompok intervensi terlihat ada kenaikan rerata frekuensi buang air kecil bayi (BAK) yang lebih besar dibandingkan dengan kelompok kontrol.

\section{Rerata Istirahat Tidur Ibu}

Berdasarkan tabel 2 menunjukkan rerata istirahat tidur sebelum diberikan perlakuan pada kelompok intervensi adalah 5,35 x/hari. Sedangkan rereta kelompok kontrol adalah 5,45 x/hari. Hasil analisis lebih lanjut didapatkan tidak ada perbedaan yang bermakna rerata frekuensi menyusui sebelum diberikan perlakuan antara kelompok intervensi dan kelompok kontrol ( $\mathrm{p}=0.602)$.

Rerata istirahat tidur setelah diberikan perlakuan pada kelompok intervensi adalah 7,35 x/hari. Sedangkan rerata pada kelompok kontrol adalah 6,40 x/hari. Hasil analisis lebih lanjut didapatkan ada perbedaan yang bermakna rerata frekuensi menyusui setelah diberikan perlakuan antara kelompok intervensi dan kelompok kontrol $(\mathrm{p}=0.000)$.

Rerata selisih istirahat tidur pada kelompok intervensi adalah 2,00 jam. Sedangkan rerata selisih pada kelompok kontrol adalah 0,95 jam. Hasil uji analisis lebih lanjut dengan uji wilcoxon dapat disimpulkan tidak ada perbedaan yang bermakna rerata selisih kenaikan frekuensi menyusui antara kelompok intervensi dengan kelompok kontrol $(\mathrm{p}=0.001)$. Adapun pengaruh pemberian pijat oksitosin oleh suami dan breast care pada kelompok intervensi terlihat ada kenaikan rerata istirahat tidur ibu yang lebih besar dibandingkan dengan kelompok kontrol. 


\section{Hasil Analisa Multivariat}

Tabel. 3

Efek Pemberian Pijat Oksitosin Oleh Suami dan Breast Care terhadap BB Bayi, Frekuensi Menyusui, Frekuensi BAB, Frekuensi BAK, Lama Tidur Bayi dan Istirahat Tidur Ibu dengan Menggunakan Uji Regresi Liner

\begin{tabular}{|c|c|c|c|c|c|c|c|c|c|c|c|c|}
\hline \multirow{2}{*}{ Faktor } & \multicolumn{2}{|c|}{ BB(gram) } & \multicolumn{2}{|c|}{$\begin{array}{l}\text { Fre.menyusui( } \\
\text { x/hari) }\end{array}$} & \multicolumn{2}{|c|}{$\mathrm{BAB}(\mathrm{x} /$ hari $)$} & \multicolumn{2}{|c|}{$\begin{array}{c}\text { BAK } \\
\text { (x/hari) }\end{array}$} & \multicolumn{2}{|c|}{$\begin{array}{c}\text { Lama tidur } \\
\text { bayi(jam/hari) }\end{array}$} & \multicolumn{2}{|c|}{$\begin{array}{l}\text { Istirahat tidur } \\
\text { (jam/hari) }\end{array}$} \\
\hline & beta & $95 \% \mathrm{CI}$ & Beta & $\begin{array}{c}95 \% \\
\text { CI }\end{array}$ & Beta & $\begin{array}{c}95 \% \\
\text { CI }\end{array}$ & beta & $\begin{array}{c}95 \% \\
\text { CI }\end{array}$ & beta & $\begin{array}{c}95 \% \\
\text { CI }\end{array}$ & beta & $95 \% \mathrm{CI}$ \\
\hline \multicolumn{13}{|l|}{ Kelompok } \\
\hline Kontrol & 0 & 0,0 & 0 & 0,0 & 0 & 0,0 & 0 & 0,0 & 0 & 0,0 & 0 & 0,0 \\
\hline Perlakuan & $\begin{array}{l}601 . \\
6^{* * *}\end{array}$ & $\begin{array}{c}533.6,6 \\
69.5\end{array}$ & $1.43^{* *}$ & $\begin{array}{l}0.42 \\
2.43\end{array}$ & 0.71 & $\begin{array}{c}- \\
0.23 \\
1.66\end{array}$ & $\begin{array}{c}1.29 \\
*\end{array}$ & $\begin{array}{l}0.30 \\
2.27\end{array}$ & $\begin{array}{c}- \\
0.071\end{array}$ & $\begin{array}{c}- \\
0.81 \\
0.67\end{array}$ & $\begin{array}{c}0.07 \\
1\end{array}$ & $\begin{array}{c}- \\
0.83,0 . \\
97\end{array}$ \\
\hline Umur ibu & $\begin{array}{c}- \\
252 . \\
9^{* * *}\end{array}$ & $\begin{array}{c}-283.3,- \\
222.5\end{array}$ & -0.36 & $\begin{array}{c}- \\
0.81 \\
0.093\end{array}$ & 0.071 & $\begin{array}{c}{[-} \\
0.49, \\
0.35]\end{array}$ & $0 . \overline{21}$ & $\begin{array}{c}- \\
0.66 \\
0.23\end{array}$ & 0.21 & $\begin{array}{c}- \\
0.12 \\
0.54\end{array}$ & $\begin{array}{l}- \\
1.1 \mathrm{e} \\
-12\end{array}$ & $\begin{array}{c}- \\
0.40,0 . \\
40\end{array}$ \\
\hline \multicolumn{13}{|l|}{ Pendidikan } \\
\hline SMP & 0 & 0,0 & 0 & 0,0 & 0 & 0,0 & 0 & 0,0 & 0 & 0,0 & 0 & 0,0 \\
\hline SMA & $\begin{array}{c}- \\
339 . \\
3^{* * *}\end{array}$ & $\begin{array}{c}-369.7,- \\
308.9\end{array}$ & 0.36 & $\begin{array}{c}- \\
0.093 \\
0.81\end{array}$ & $\begin{array}{c}0.86^{* *} \\
*\end{array}$ & $\begin{array}{c}0.43 \\
1.28\end{array}$ & $\begin{array}{c}0.07 \\
1\end{array}$ & $\begin{array}{c}- \\
0.37 \\
0.51\end{array}$ & 0.071 & $\begin{array}{c}- \\
0.26 \\
0.40\end{array}$ & 0.71 & $\begin{array}{c}0.31,1 . \\
12\end{array}$ \\
\hline PT & $\underset{* * *}{99.3}$ & $\begin{array}{c}56.3,14 \\
2.3\end{array}$ & $0.64^{*}$ & $\begin{array}{c}0.006 \\
7,1.2 \\
8\end{array}$ & $1.14^{* *}$ & $\begin{array}{c}0.54 \\
1.74\end{array}$ & 0.36 & $\begin{array}{c}- \\
0.27 \\
0.98\end{array}$ & $\begin{array}{c}- \\
0.071\end{array}$ & $\begin{array}{c}- \\
0.54 \\
0.40\end{array}$ & 1.14 & $\begin{array}{c}0.57,1 . \\
71\end{array}$ \\
\hline \multicolumn{13}{|l|}{ Paritas } \\
\hline Primipara & 0 & 0,0 & 0 & 0,0 & 0 & 0,0 & 0 & 0,0 & 0 & 0,0 & 0 & 0,0 \\
\hline Multipara & $\begin{array}{l}497 . \\
1^{* * *}\end{array}$ & $\begin{array}{c}444.5,5 \\
49.8\end{array}$ & 0.64 & $\begin{array}{c}- \\
0.14 \\
1.42\end{array}$ & 0.57 & $\begin{array}{c}- \\
0.16, \\
1.30\end{array}$ & 0.57 & $\begin{array}{c}- \\
0.19 \\
1.34\end{array}$ & 0.071 & $\begin{array}{c}- \\
0.50 \\
0.64\end{array}$ & $\underset{*}{0.71}$ & $\begin{array}{c}0.016 \\
1.41\end{array}$ \\
\hline
\end{tabular}

95\% confidence intervals in brackets, aic= LR Test from Aka iki, df_m= degress of freedom of the model ${ }^{*} p<0.05,{ }^{* *} p<0.01,{ }^{* * *} p<0.001$

Berdasarkan tabel 3 dari hasi uji regresi linear dengan analisis anova repeated measured dapat dilihat nilai pvlue $<0.001$, artinya umur pada kedua kelompok sama. Pada tingkat pendidikan ibu pada kedua kelompok sama dilihat dari nilai $(\mathrm{p}<0,001)$ artinya pendidikan pada kedua kelompok sama. Pada kelompok paritas pada kelompok kontrol dan intervensi multipara nilai $(\mathrm{p}<0,001)$ artinya paritas pada kedua kelompok sama. Dapat disimpulkan bahwa tidak terdapat efek umur, pendidikan, dan paritas terhadap produksi air susu ibu (ASI).

Berdasarkan tabel 3 dari uji regresi liner dengan analisis anova repeated measured dapat dilihat buang air besar bayi (BAB) (x/hari) semakin banyaknya perlakuan tidak mempengaruhi buang air besar bayi (BAB) dilihat dari 0.71 , artinya tidak ada pengaruh pijat oksitosin oleh suami terhadap buang air besar bayi (BAB). Lama tidur bayi (jam/hari) semakin banyaknya perlakuan tidak mempengaruhi kualitas tidur bayi dilihat dari nilai -0.071 , artinya tidak ada pengaruh pijat oksitosin oleh suami terhadap lama tidur bayi. Semakin banyaknya perlakuan tidak mempengaruhi kualitas istirahat tidur ibu dilihat dari nilai 0.071 , artinya tidak ada pengaruh perlakuan pijat 
oksitosin oleh suami dan istirahat tidur ibu akan tetapi semakin banyak perlakuan kualitas istirahat ibu semakin meningkat. Untuk berat badan bayi ada kenaikan berat badan bayi setelah diberikan intervensi nilai pvalue $601.6(\mathrm{p}<0.001)$, frekuensi menyusui (x/hari) setelah diberikan perlakuan ada kenaikan frekuensi menyusui dilihat dari nilai $\mathrm{p}$ value $1.43(\mathrm{p}<0.01)$, artinya berat badan bayi, frekuensi menyusui, ada pengaruh signifikan setelah diberikan perlakuan pijat oksitosin oleh suami dan breast care.

\section{PEMBAHASAN \\ Karakteristik Responden}

Penelitian ini dilakukan pada ibu nifas dibagi menjadi kelompok intervensi dan kelompok kontrol, pada kelompok intervensi yang diberikan pijat oksitosin oleh suami dan breast care, pada kelompok kontrol breast care selama 15 hari, untuk melihat kenaikan produksi air susu ibu (ASI) yaitu: (berat badan bayi, frekuensi menyusui, lama tidur bayi, frekuensi buang air besar bayi (BAB), frekuensi buang air kecil bayi (BAK), dan istirahat ibu). Dari hasil pengumpulan data karakteristik partisipan meliputi umur ibu, umur suami, pendidikan ibu dan suami, pekerjaan dan paritas. Data karakteristik tersebut diuji statistik untuk mengetahui homogenitasnya dan di sajikan dalam bentuk dist.

Hasil penelitian ini sejalan dengan dengan Rahayu (2014) menunjukkan rerata karakteristik umur 26-35 responden pada kelompok intervensi dan kelompok kontrol paling banyak sebesar 62,5\%. Pada Murdiyaningsih (2010) rerata karakteristik umur responden $<35$ sebesar $80 \%$. Usia merupakan faktor tidak langsung yang mempengaruhi produksi ASI. Usia reproduksi<35 tahun merupakan usia terbaik untuk menghasilkan produksi ASI yang lebih banyak dibandingkan ibu yang sudah tua.

Pada kelompok intervensi dan kelompok kontrol sebelum diberikan perlakuan penimbangan berat badan bayi,frekuensi menyusui, frekuensi buang air besar bayi(BAB), frekuensi buang air kecil bayi (BAK), lama tidur bayi, dan istirahat ibu. Kegiatan tersebut dilakukan oleh enumerator yaitu bidan dan dilakukan Wilayah kerja Puskesmas Pudakpayung Kota Semarang.

Massage atau pijat adalah tindakan melakukan tekanan tangan pada jaringan lunak, biasanya otot, tendon atau ligament-ligament, tanpa menyebabkan gerakan atau perubahan posisi sendi untuk meredakan nyeri, menghasilkan relaksasi, dan memperbaiki sirkulasi. Oksitosin adalah salah satu dari dua hormon yang dibentuk oleh sel-sel neuronal nuclei hipotalamik dan disimpan dalam lobus posterior pituitary, hormon lainnya adalah vasopressin. Hormon ini memiliki kerja mengontraksi uterus dan menginjeksi ASI (Morhenn, 2012).

Pijat oksitosin merupakan salah satu solusi untuk mengatasi ketidaklancaran produksi ASI. Pijat oksitosin adalah pemijatan pada sepanjang tulang belakang (vertebrae) sampai tulang costae kelima-keenam dan merupakan usaha untuk merangsang hormon prlaktin dan oksitosin setelah melahirkan. Hormon prolaktin memegang peranan penting dalam produksi ASI, kadar hormon prolaktin pada ibu yang menyusui akan menjadi normon setelah 3 bulan pasca persalinan. Pada hari ke dua dan ketiga kadar estrogen dan progesteron menurun drastis, sehingga pengaruh prolaktin lebih tinggi dan terjadi sekresi ASI. Dengan menyusui dini, terjadilah perangsangan putting susu terbentuklah prolaktin oleh hipofisis anterior sehingga sekresi air susu ibu (ASI) semakin lancar (Anuhgera D, 2017). 
Hormon prolaktin mengalami peningkatan yang lebih tinggi pada kelompok pijat oksitosin oleh suami karena dipengaruhi oleh faktor psikologis. Pada saat dilakukannya pijat oksitosin oleh suami yang merangsang saraf parasimpatis dapat menghasilkan rasa rileks dari hipofisis posterior dan menghasilkan endorpin dari hipofisis anterior. Sehingga membuat ibu nifas semakin merasa rileks pada saat menyusui. Semakin sering ibu memberikan ASI maka produksi air susu ibu (ASI) juga akan bertambah, dan secara fisiologis hormon prolaktin akan meningkat. Refleks prolaktin dan refleks aliran (let down refleks) sangat menentukan keberhasilan selama proses menyusui. Refleks prolaktin secara hormonal untuk memproduksi Rangsangan ini lanjutan ke hipotalamus melalui mendulla spinalis hipotalamus dan akan menekan pengeluaran faktor penghambat prolaktin dan sebaliknya merangsang pengeluaran pemacu sekresi prolaktin. Rangsangan tersebut terus diteruskan ke hipofisi melalui nervus, kemudian ke lobus anterior. Dari lobus ini akan mengeluarkan hormon prolaktin, masuk ke peredaran darah sampai pada kelenjar-kelenjar pembuat ASI, sel-sel alveoli akan terangsang untuk membuat air susu. Pada ibu menyusui prolaktin akan menurun dalam keadaan stress, pengaruh phisikis (gelisah, kurang percaya diri, takut, cemas), anastesi, operasi.

Frekuensi dilakukannya pijat oksitosin juga akan mempengaruhi produksi air susu ibu(ASI), dalam peneltian ini Pijat oksitosin oleh suami dilakukan dua kali sehari pagi dan sore hari. Pijat oksitosin lebih efektif apabila dilakukan pagi dan sore selama 15 menit dapat mempengaruhi produksi air susu ibu (ASI) pada ibu nifas. Pijat oksitosin pada punggung ibu dapat meningkatkan kadar hormon prolaktin ibu. Hal ini sesuai dengan penelitian yang dilakukan oleh Kurniawati pada tahun 2014 membuktikan bahwa ibu postpartum yang diberikan massage di daerah punggung mulai dari batas leher sampai batas bawah scapula di sekitar ruas tulang bekalang selama 15 menit dapat meningkatkan kadar oksitosin dari prolaktin dalam darah. Penelitian Suwondo pada tahun 2015 dimana hasil penelitian menunjukkan terjadi peningkatan kadar hormon prolaktin sebelum dan sesudah diberikan pijat oksitosin. Penelitian Machmudah pada tahun 2017 bahwa pijat oksitosin efektif dapat meningkatkan produksi air susu ibu (ASI). Sedangkan pada penelitian indriyani pada tahun 2006 menunjukkan terdapat peningkatan hormon prolaktin dan berat badan bayi pada kelompok intervensi yang diberikan pijat oksitosin.

Adapun variabel confounding pada penelitian ini umur ibu/umur suami, pendidikan, pekerjaan. Hasil penelitian menunjukkan rerata umur responden sama antra kelompok intervensi dan kelompok kontrol. Sehingga faktor umur pada penelitian ini dapat dikendalikan. Pengendalian umur responden dilakukan dilakukan dengan kriteria inklusi umur responden. Umur yang aman untuk kehamilan, persalinan dan menyusui adalah, dikarenakan umur sesuai dengan masa reproduksi yaitu sangat baik dan sangat mendukung dalam pemberian air susu ibu (ASI) eklusif.

Pada variabel pendidikan, hasil penelitian menunjukkan rerata pendidikan responden sama antara kelompok intervensi dan kelompok kontrol. Sehingga faktor pendidikan responden pada penelitian ini dapat dikendalikan. Pendidikan merupakan salah satu faktor penting untuk mendapatkan dan menerima secara lebih mudah informasi, karena pendidikan dapat mempengaruhi kemampuan orang tua dalam melakukan perawatan terhadap bayinya supaya sehat.

Pada variabel pekerjaan, hasil penelitian menunjukkan rerata pekerjaan responden sama antara kelompok intervensi dan kelompok kontrol. Sehingga faktor pekerjaan responden pada penelitian ini dapat dikendalikan. Ibu yang tidak bekerja memiliki 
waktu yang lebih lama bersama bayi sehingga memiliki kesempatan untuk dapat memberikan air susu ibu (ASI) pada bayi secara on demand.

$\mathrm{Ibu} / \mathrm{responden}$ yang bekerja merupakan salah satu kendala yang menghambat pemberian ASI eksklusif. Produksi ASI ibu bekerja memang akan berkurang. Hal ini antara lain karena tanpa disadari ibu mengalami stress akibat berada jauh dari sang buah hati. Ibu bekerja ternyata dapat mempengaruhi produksi air susu ibu (ASI) walaupun sudah dijelaskan tentang berbagai cara teknik menyusui, cara peningkatan produksi ASI dan lain sebagainya. Banyak ibu bekerja yang menghentikan pemberian air susu ibu(ASI), padahal bekerja bukan alasan untuk menghentikan pemberian ASI secara eksklusif meskipun cuti melahirkan hanya 3 bulan. Menurut penelitian Budiarti pada tahun 2009 menunjukkan bahwa ibu bekerja atau tidak bekerja tidak mempengaruhi produksi ASI karena informasi dan lingkungan kerja dan memberikan pengertian pengetahuan tentang produksi ASI.

Menurut penelitian Desmawati pada tahun 2018 menunjukkan bahwa ibu yang yang bekerja tidak mempengaruhi pemberian air susu ibu (ASI) kepada bayinya. Dengan pengetahuan yang benar tentang menyusui, seorang ibu yang bekerja dapat tetap memberikan air susu ibu (ASI) secara eksklusif.

Pada variabel pola istirahat tidur partisipan pada kelompok yang diberikan perlakuan didapatkan pola istirahat tidur adalah 5 jam/hari dan pada kelompok kontrol rata-rata pola istirahat tidur adalah 5 jam/hari. Dapat disimpulkan bahwa kedua kelompok mempunyai kesetaraan pola istirahat tidur yang homogen. Bila ibu kurang istirahat tubuh akan mengalami kelemahan dan menjalankan fungsinya sehingga dapat mempengaruhi status kesehatan ibu karena tubuh tidak sehat input makanannya kurang atau kurang darah untuk membawa bahan-bahan yang akan diolah oleh sel-sel acini tersebut sehingga pembentukan dan pengeluaran ASI akan terhambat.

Faktor istirahat mempengaruhi produksi air susu ibu (ASI), apabila kondisi ibu terlalu capek, kurang istirahat maka air susu ibu (ASI) juga berkurang. Faktor lainnya yang juga mempengaruhi dalam pengeluaran dan produksi air susu ibu (ASI) adalah pola istirahat. Pada bulan-bulan pertama, ibu tentu akan merasa sangat kurang istirahat karena pola tidur bayi masih belum teratur. Hal ini bisa diantisipasi dengan cara mengikuti pola tidur bayi. Ibu dapat tidur saat bayi tertidur dan bangun saat bayi bangun untuk disusui. Dengan mengikuti pola tidur bayi ibu bisa terbantu untuk mendapatkan waktu istirahat yang cukup. Penelitian yang dilakukan oleh Kendall pada tahun 2011 menunjukkan bahwa ibu yang memberikan air susu ibu (ASI) sepenuhnya kepada bayi justru memilih waktu tidur bayi lebih di bandingkan ibu yang memberikan susu kombinasi atau susu formula kepada bayinya.

Paritas akan mempengaruhi keaktifan dari hormon-hormon termasuk hormon oksitosin yang akan mempengaruhi produksi air susu ibu (ASI). Pada paritas yang tinggi secara anatomi kelenjar alveolus yang ada dalam payudara sudah tidak maksimal dalam memproduksi air susu ibu (ASI), sehingga meskipun dilakukan perparangsangan pada area tulang belakang selama dua kali sehari akan sedikit berpengaruh untuk keluarnya oksitosin dibandingkan dengan ibu yang memiliki paritas rendah. Pada ibu dengan paritas tinggi oksitosin akan tetap terproduksi namun tidak sebanyak pada ibu dengan paritas rendah. Hal ini akan menyebabkan pada ibu dengan paritas rendah cenderung produksi air susu ibu (ASI) yang dikeluarkan lebih baik dibandingkan dengan ibu yang memiliki paritas tinggi.

Ibu multipara menunjukkan produksi air susu ibu (ASI) yang lebih banyak dibandingkan dengan primipara pada hari keempat nifas. Kenaikan jumlah paritas 
menyebabkan perubahan produksi air susu ibu (ASI) walaupun pengalama dan keyakinan ibu pada saat menyusui sebelumnya akan mempengaruhi perilaku ibu pada proses menyusui selanjutnya. Jika ibu berhasil pada saat menyusui. Keyakinan ibu ini dapat merangsang pengeluaran oksitosin sehingga air susu ibu (ASI) dapat keluar dengan lancar.

Dari hasil penelitian di Kudus karaktekteristik paritas tidak mempengaruhi kadar prolaktin ibu post partum, senada dengan penelitian di Jogjakarta bahwa paritas tidak mempengaruhi pelaksanaan inisiasi menyusui dini pada ibu bersalin. Artinya hasil penelitian ini menunjukkan bahwa perlakuan pemijatan oksitosin oleh suami terbukti meningkatnya rangsangan pada impuls syaraf aferens sehingga hormon oksitosin meningkat, dengan peningkatan hormon tersebut akan memberikan umpan balik terhadap peningkatan hormon prolaktin.

\section{Pijat Oksitosin oleh Suami Dapat Meningkatkan Produksi Air Susu Ibu (ASI)}

Hasil penelitian menunjukkan pada perbedaan bermakna produksi air susu ibu (ASI) pada kelompok kontrol dan kelompok intervensi. Sehingga dapat disimpulkan bahwa pijat oksitosin oleh suami dapat meningkatkan produksi air susu ibu (ASI). Teori lain dikemukakan oleh Morhenn pada tahun 2012 menjelaskan bahwa pemijatan merupakan salah satu stimulasi sensorik somatik melalui penekanan jaringan lunak yang dapat menghubungkan jalur sistem syaraf perifer terhadap sistem syaraf pusat sehingga mampu menghasilkan reflek pada sistem syaraf otonom dan mempengaruhi kontrol neuroendokrin didalam tubuh manusia. Penelitian dilakukan Widayanti pada tahun 2014 menunjukkan bahwa rangsangan berupa sentuhan, kehangatan, sensasi alfaktori, penekanan ringan dan pemijatan dapat menstimulasi peningkatan pelepasan oksitosin didalam sirkulasi darah dan didalam cairan serebrospinal. Frekuensi dilakukan pijat oksitosin juga akan mempengaruhi produksi air susu ibu (ASI), dalam penelitian ini pijat oksitosin dua kali sehari pagi dan sore hari. Pijat oksitosin lebih efektif apabula dilakukan dua kali pagi dan sore. Pijat oksitosin yang dilakukan sehari dua kali dapat mempengaruhi produksi air susu ibu (ASI) pada ibu nifas. Pemijatan oleh suami dapat membantu ibu nifas untuk meningkatkan relaksasi dan kenyamanan sehingga diharapkan produksi air susu ibu (ASI) dapat meningkat.

Peningkatan produksi air susu ibu (ASI) dapat dilihat dengan indikator berat berat badan bayi. Rerata berat badan bayi setelah diberikan perlakuan pada kelompok intervensi dan kelompok kontrol. Hasil uji analisis dengan mann-whitney didapatkan ada perbedaan yang bermakna rerata berat bayi setelah diberikan perlakuan antara kelompok intervensi dan kelompok kontrol. Hasil analisis dengan menggunakan uji regresi liner ada perbedaan yang bermakna rerata berat badan badan bayi setelah diberikan perlakuan antara kelompok intervensi dan kelompok kontrol.

Pada awal-awal kelahiran, BB bayi tidak turun melenihi 5\% sampai 10\% dari BB lahir pada minggu pertama kelahiran. Air susu ibu (ASI) merupakan suatu cairan yang terbentuk dari campuran dua zat yaitu lemak dan air yang terdapat dalam larutan protein. Laktosa dan garam-garam anorganik yang dihasilkan oleh kelenjar payudara ibu, dan bermanfaat sebagai makanan bayi. Apabila kebutuhan nutrisi bayi tercukupi, maka berat badan bayi akan bertambah.

Hasil penelitian ini sesuai dengan penelitian yang dilakukan khanal tahun 2016 bahwa ibu yang diberikan back massage menunjukkan peningkatan berat badan bayi. Penelitian Morhenn pada tahun 2012 dimana hasil penelitianmenunjukkan ada peningkatan $\mathrm{BB}$ bayi setelah diberikan pijat oksitosin.Hal ini didukung penelitian yang 
dilakukan oleh Suryani pada tahun 2011 yang menyatakan bahwa terdapat perbedaan signifikan antara berat badan bayi yang diberi ASI saja dan makanan atau minuman tambahan.

Sesuai dengan penelitian ini kenaikan berat badan bayi selama 14 hari setelah ibu nifas mendapatkan pijat oksitosin oleh suami, produksi ASI semakin meningkat sehingga frekuensi bayi menyusu lebih sering dan lebih lama yang berdampak pada kenaikan berat badan bayi.

Indikator lain untuk melihat bahwa ASI tercukupi bagi bayi adalah frekuensi BAB bayi. Hasil analisis uji mann-whitney didapatkan tidak ada perbedaan bermakna antara kelompok intervensi dan kelompok kontrol. Hasil analisis lebih lanjut dengan menggunakan uji regresi linear didapatkan ada perbedaan yang bermakna rerata $\mathrm{BAB}$ bayi setelah diberikan perlakuan antara kelompok intervensi dan kelompok kontrol.

Buang air besar bayi (BAB) yang berupa mekonium akan keluar dalam kurun waktu 24 jam bayi lahir. Selanjutnya warna tinja yang disusui dengan ASI akan berwarna kuning dan lembek dengan frekuensi. Penelitian ini sesuai dengan hasil penelitian Machmudah pada tahun 2011 dimana hasil penelitian menunjukkan bahwa terjadi peningkatan frekuensi buang air besar bayi (BAB) setelah dilakukan pijat oksitosin dan oketani paling tinggi frekuensi buang air besar bayi (BAB) dalam sehari, dengan rata-rata . Bayi yang mendapat ASI akan berbeda dengan bayi yang diberi susu formula. Pada bayi yang diberikan ASI pola buang air besar bayi (BAB), BAB yang dihasilkan adalah berwarna kuning keemasan, tidak terlalu encer dan tidak terlalu pekat, sedangkan bayi yang mendapatkan susu formula pola $\mathrm{BAB}$ nya 1 kali sehari, BAB berwarna putih pucat. ASI sangat mudah dicerna sehingga bayi akan lebih sering BAB.

Selain frekuensi buang air besar bayi (BAB), indikator lain untuk melihat bahwa ASI tercukupi bagi bayi adalah frekuensi buang air besar bayi (BAB). Rerata frekuensi buang air kecil bayi (BAK) setelah diberikan perlakuan pada kelompok intervensi sedangkan pada kelompok kontrol. Hasil analisis dengan uji mann-whitney didapatkan tidak ada perbedaan yang bermakna rerata frekuensi buang air kecil bayi (BAK) setelah diberikan perlakuan antara kelompok intervensi dan kelompok kontrol.

Hasil analisis lebih lanjut dengan menggunakan uji regresi linear didapatkan ada perbedaan yang bermakna rerata frekuensi buang air kecil bayi (BAK) setelah diberikan perlakuan antara kelompok intervensi dan kelompok kontrol. Frekuensi frekuensi buang air kecil bayi (BAK) yang mendapatkan ASI cukup dengan warna urine kuning dan jernih. Pola eliminasi bayi tergantung dari intake yang bayi dapatkan, bayi yang minum ASI, warna unine jernih, bau khas urine. Penelitian oleh Suryani tahun 2013 dimana frekuensi buang air kecil bayi (BAK) bayi pada hari pertama setelah lahir adalah 6 kali dalam 24 jam, pada minggu kedua 10 kali dalam 24 jam, sehingga hasil penelitiannya menunjukkan ada peningkatan frekuensi buang air kecil bayi (BAK) setelah diberikan pijat oksitosin pada minggu kedua. Penelitian Machmudah pada tahun 2011 juga menunjukkan bahwa ada peningkatan frekuensi buang air kecil bayi (BAK) setelah menunjukkan bahwa ada peningkatan frekuensi BAK bayi setelah dilakukan pijat oksitosin dan oketani yaitu 12 kali sehari. Hasil penelitian Widayanti pada tahun 2014 menyebutkan bahwa produksi ASI dapat dinilai dari frekuensi buang air kecil bayi (BAK) yaitu sebanyak 6-8 kali sehari.

Indikator lain untuk melihat bahwa ASI tercukupi bagi bayi adalah lama tidur bayi. Hasil analisis lebih lanjut didapatkan tidak ada perbedaan antara lama tidur bayi antara kelompok intervensi dan kelompok kontrol. 
Rerata selisih lama tidur bayi setelah diberikan perlakuan pada kelompok intervensi, sedangkan rerata lama tidur bayi setelah diberikan perlakuan pada kelompok kontrol. Hasil analisis lebih lanjut dengan uji mann-whitney ada perbedaan bermakna antara kelompok intervensi dan kelompok kontrol.

Hasil analisis lebih lanjut dengan menggunakan uji regresi liner lama tidur bayi didapatkan tidak terdapat signifikan lama tidur bayi setelah diberikan perlakuan pada kelompok intervensi.

Lama tidur bayi yang cukup ASI setelah menyusui dalam sehari. Hasil penelitian ini sesuai dengan penelitian Suryani pada tahun 2011 dimana lama tidur bayi menunjukkan ada perbedaan pada hari pertama dan minggu kedua serelah dilakukan pijat oksitosin. Bayi akan tidur tenang/nyenyak setelah menyusu (Suryani 2011). Kecukupan pemberian ASI juga ditujukkan oleh perilaku bayi yang biasanya tenang, tidak rewel dan tidur pulas. Namun perlu diperhatikan juga bahwa kesuksesan pemberian ASI juga dipengaruhi oleh tingkat kenyaman ibu yang secara tidak menjadwalkan pemberian ASI juga dipengaruhi oleh tingkat kenyamanan ibu yang secara tidak langsung akan mempengaruhi produksi ASI. Ibu sebaiknya tidak menjadwalkan pemberian ASI. Menyusui paling baik dilakukan sesuai permintaan bayi (on demand). Produksi ASI sangat mempengaruhi oleh seringnya bayi menyusu. Semakin sering bayi disusui maka jumlah volume ASI yang diproduksi akan semakin banyak karena semakin tinggi kadar oksitosin pada peredaran darah yang akan merangsang prolaktin untuk terus memproduksi ASI, berat badan bayi akan bertambah, frekuensi buang air besar bayi (BAB) dan frekuensi buang air kecil bayi (BAK) akan lebih sering dari bayi akan merasa tenang, tidak rewel dan tidur pulas. Pijat oksitosin oleh suami dapat membantu ibu nifas untuk meningkatkan relaksasi dan kenyamanan sehingga produksi ASI dapat meningkat.

Pada variabel frekuensi menyusui, hasil penelitian didapatkan frekuensi menyusui pada kelompok intervensi,pada kelompok kontrol rata-rata frekuensi menyusui. Dapat disimpulkan bahwa kedua kelompok mempunyai kesetaraan frekuensi menyusui yang sama atau homogen.

Adapun pengaruh pemberian pijat oksitosin oleh suami pada kelompok intervensi terlihat ada kenaikan rerata kadar berat badan bayi yang besar dibandingkan dengan kelompok kontrol. Hasil uji mann-whitney dapatkan disimpulkan ada perbedaan yang bermakna rerata selisih kenaikan kadar hormon prolaktin antara kelompok intervensi dan kelompok kontrol.

Hasil analisis dengan menggunakan uji multivariat frekuensi menyusui setelah diberikan intervensi lebih besar dibandingkan dengan kelompok kontrol. Hasil analisis lebih lanjut dengan uji regresi liner didapatkan ada perbedaan yang bermakna rerata frekuensi menyusui setelah diberikan perlakuan antara kelompok intervensi dan kelompok kontrol.

Menyusui bayi setelah melahirkan sangat penting karena dengan menyusui bayi lebih dini terjadi perangsangan areola dan terbentuklah prolaktin. Pengeluaran air susu dari kelenjar mammae adalah faktor penting dalam kelanjutan produksinya, terdapat bahan kimia (penghambat) dalam ASI yang sudah dirancang untuk menghentikan produksi tidak digunakan, apabila ASI yang sudah diproduksi tidak dihisap atau dikeluarkan dari kelenjar mammae dalam waktu lama, bahan kimia (penghambat) atau inhibitor autokrin ini akan menghentikan sel-sel pembuat ASI diproduksi. Keteraturan bayi menghisap menjadikan produksi ASI semakin bertambah setiap hari ditunjang juga oleh nutrisi dari ibu. 
Semakin sering bayi menyusu pada payudara ibu, maka produksi dan pengeluaran ASI akan semakin banyak. Pada bulan-bulan pertama setelah melahirkan untuk menjamin produksi dan pengeluaran air susu ibu (ASI). Frekuensi menyusui berkaitan dengan kemampuan stimulasi kedua hormon dalam kelenjar payudara, yakni hormon prolaktin dan oksitosin (Widiyanto, 2012). Hal ini sesuai dengan penelitian Suryani dimana hasil penelitian frekuensi menyusui pada hari pertama setelah lahir adalah 4-5 kali dan meningkat pada minggu kedua. Sehingga hasil penelitian menunjukkan ada peningkatan frekuensi menyusui setelah diberikan pijat oksitosin pada minggu ke 2 . Hasil penelitian dari Muchmudah pada haun 2011 menunjukkan bahwa frekuensi menyusui setelah pijat oksitosin dan oketani yaitu 12 kali sehari (Suryani, 2011). Refleks prolaktin dan refleks aliran (let down refleks) sangat menentukan keberhasilan selama proses menyusui.

Dalam penelitian ini didapatkan pengukuran akhir pada hari ke 15 kelompok intervensi terjadi peningkatan produksi air susu ibu (ASI) yang sangat bermakna terhadap produksi air susu ibu (ASI) dengan meningkatnya berat badan bayi, frekuensi buang air besar (BAB), frekuensi buang air kecil (BAK), frekuensi menyusui, lama tidur bayi, dan istirahat ibu. Dengan demikian dapat disimpulkan bahwa produksin air susu ibu (ASI) pada kelonmpok intervensi pijat oksitosin oleh suami dan breast care berpengaruh signifikan dibandingkan kelompok kontrol.

\section{SIMPULAN}

Pemberian pijat oksitosin oleh suami dari hari pertama sampai hari ke 14 pada ibu nifas normal berpengaruh terhadap peningkatan produksi ASI yang ditunjukan dari: Berat badan bayi, frekuensi menyusui, frekuensi buang air besar bayi (BAB), Frekuensi buang air kecil bayi (BAK), lama tidur bayi, dan istirahat tidur ibu. Pemijatan oksitosin oleh suami dapat dilakukan dan diterapkan pada ibu fase masa nifas.

\section{SARAN}

Bagi peneliti selanjutnya dapat mengukur intesitas tekanan pemijatan oksitosin yang lebih efektif dan akurat pada ibu nifas. Makanan ibu nifas hari 1 (pertama) sampai hari ke 14 harus memperhatikan food recall agar dapat mengukur recall makanan dan energi untuk ibu nifas.

\section{DAFTAR PUSTAKA}

Aidam, B. A., Perez, P. R., Lartey, A., Aidam, J. (2005). Factors Associated with Exclusive Breastfeeding in Accra, Ghana. European Journal of Clinical Nutrition. 59, 789-796. (diunduh 17 Mei 2011)

Ahn, S., Kim, J., \& Cho, J. (2011). Effects of Breast Massage on Breast Pain, Breastmilk Sodium, and Newborn Suckling in Early Postpartum Mothersof. Academy of Nursing, (4), 41

Anuhgera, D., Kuncoro, T., Sumarni, S., Mardiyono, M., \& Suwondo, A .(2017). Hypnotherapy is More Effective than Acupressure in the Production of Prolactin Hormone and Breast Milk among Women Having Given Birth with Caesarean Section. Medicine and Clinical Science

Budiarti, T. (2009). Efektifitas Pemberian Paket Sukses ASI terhadap Produksi ASI Ibu Menyusui dengan Seksio Caesarea di Wilayah Depok Jawa Barat. Tesis. Depok: FIK UI. Tidak dipublikasikan

Darmastuti. (2018). Pengaruh Pijat Oksitosin terhadap Kadar Hormon Prolaktin dan Produksi ASI pada Ibu Sektio Caesarea (Studi kasus di RSUD kota Semarang) 
Dewi., Gusti, K., \& Eneng, Y. S. (2017). Hubungan antara Karakteristik Responden dalam Pemberian Asi Eksklusif dengan Status Gizi Bayi Umur 6-12 Bulan di Posyandu Dahlia Desa Bangbayang Tahun 2015. Jurnal Impuls, 1(2), 78-82

Eko, M. (2011). Efektivitas Kombinasi Teknik Marmet dan Pijat Oksitosin terhadap Produksi ASI Ibu Post Partum di Rumah Sakit Wilayah Jawa Tengah. Keperawatan Soedirman. The Soedirman Journal of Nursing, 6

Hani, R. M. (2014). Hubungan Dukungan Suami terhadap Keberhasilan Pemberian ASI Eksklusif pada Ibu Primipara di Wilayah Kerja Puskesmas Pisangan. Jakarta. Fakultas Kedokteran dan Ilmu Kesehatan.

http://health.detik.com/read/2011/08/15/095530/170688/1201/dr-utami-roesli-pejuangasi-yang-pernah-gagal-menyusui

Hubertin., Sri, P. (2004). Konsep Penerapan ASI Eksklusif. Jakarta: EGC:11

Indriyani, D. (2006). Pengaruh Menyusui Dini dan Teratur terhadap Produksi ASI pada Ibu Post Partum dengan Sectio Caesarea di RSUD Dr. Soebandi Jember dan Dr. H.Koesnadi Bondowoso. Depok: FIK UI

Jateng., Dinkes. Dinas Kesehatan. P.K.P.J. Tengah. (2013). ed: Profil Kesehatan Provinsi Jawa Tengah

Karuniawati, B., Fauziandari, E. N., \& Wulandari, A. (2014). Studi Komparasi Teknik Marmet dan Pijat Oksitosin terhadap Produksi Asi pada Ibu Post Partum Primipara di Rumah Sakit Wilayah Daerah Istimewa Yogyakarta. Jurnal Kesehatan Karya Husada

Khairani, L. (2012). Pengaruh Pijat Oksitosin terhadap Involusi Uterus pada Ibu Post Partum di Ruang Post Partum Kelas III RSHS Bandung. Students e-Journal, 1, 33

Kim, S. (2018). Interventions Promoting Exclusive Breast Feeding Up to Six Months after Birth: A systematic Review and Meta-Analysis of Randomized Controlled Trials. International Journal of Nursing Studies

Latifah, J., Wahid, A., \& Agianto, A. (2015). Perbandingan Breast Care dan Pijat Oksitosin terhadap Produksi ASI pada Ibu Post Partum Normal. Dunia Keperawatan, 3, 34-43

Lussier, M. M., Brownell, E. A., Proulx, T. A., Bielecki, D. M., Marinelli, K. A., Bellini, S. L., \& Hagadorn, J. I. (2015). Daily Breastmilk Volume in Mothers of Very Low birth weight neonates: a repeated-measures randomized trial of hand expression versus electric breast pump expression. Breast Feeding Medicine, $10(6), 312-317$

Machmudah, M., \& Khayati, N. (2017). Breastmilk Production of Mother with Post Caesarean Section Given Oketani and Oxitocyn Massage. Jurnal Ners, 9(1): 104110

Mardianingsih, Eko. (2010). Efektitas Kombinasi Teknik Marmet dan Pijat Oksitosin terhadap Produksi ASI Ibu Seksio Caesarea di Wilayah Rumah Sakit Daerah Jawa Tengah

Morhenn, Beavin, Zak. (2012). Massage Increases Oxytocin and Reduces Adrenocorticotropin Hormone in Humans. Alternative Therapies 18:6. Cetakan I. Yogyakarta: Graha Ilmu

Rahayu, RY., \& Sari, S. (2014). "Pengetahuan Ibu Primipara tentang Faktor-Faktor yang Mempengaruhi Produksi ASI”. Vol.1 No.1 Tahun 2012 Halaman 108-115

Rempel, L. A., Rempel, J. K., \& Moore, K. C. (2017). Relationships Between Types of Father Breast Feeding Support and Breast Feeding Outcomes. Maternal \& child nutrition, 13(3), 3-13 
Riorda, J. (2005). Anatomy and Physiology of Lactation in Breastfeeding and Human Lactation. Human Lactation 3

Roesli, U. (2011). Detik Health, Pejuang ASI yang Gagal Menyusui

Sastroasmoro., Sudigdo \& Ismael, S. (2011). Dasar-Dasar Metodologi Penelitian Klinis. Bandung: Sagung Seto

SDKI, Kemenkes RI. (2012). Survey Demografi dan Kesehatan Indonesia. J. K. RI.2012., ed

Semarang., Dinkes Jateng Kabupaten. (2015). Dinas Kesehatan Kabupaten Semarang,. C.A.d.K.S. Tahun, ed

Sintesis., Anwar, R. (2010). Fungsi dan Interprestasi Pemeriksaan Hormon Reproduksi. Obsteric dan Ginekologi FK UNPAD

Siregar. (2006). Pemberian ASI Eksklusif dan Faktor-Faktor yang Mempengaruhinya. Sumatra Utara: Universitas Sumatera

Suryani, N. D., \& Mularsi, S. (2011). Hubungan Dukungan Suami dengan Pelaksanaan Inisiasi Menyusui Dini pada Ibu Post Partum di BPS Kota Semarang, Dinamika Kebidanan, 1(1)

Suwondo, A., \& Wahyuni, S. (2015). Efektifitas Kombinasi Pijat Oksitosin Tehnik Effleurage dan Aromaterapi Rose terhadap Kadar Hormon Prolaktin Ibu Post Partum Normal di Wilayah Puskesmas Dawe Kudus Tahun 2013. Jurnal Ilmu dan Teknologi Kesehatan, 5(1)

UNICEF. (2014). ASI Penyelamat Hidup dan Efektif di Dunia: http://www.unicef.org/indonesia/id/

WHO, World Health Statistics. (2013). Publication Data, WHO Press, Geneva

Widayanti, W. (2014). Efektivitas Metode "Speos" (Stimulasi Pijat Endorphin, Oksitosin dan Sugestif) terhadap Pengeluaran Asi pada Ibu Nifas: (Quasi Ekperimen, di BPM Wilayah Kabupaten Cirebon ). kedektoren

Widiyanto S. Avianti D, Tyas M. (2012). Hubungan Pendidikan dan Pengetahuan Ibu tentang ASI Eksklusif dengan Sikap terhadap Pemberian ASI Eksklusif. Jurnal Kedokteran Muhhamadiyah, 1(1) 